\title{
"A Problem of Slum Dwellings and Relatively Ignorant Parents": A History of Victim Blaming in the Lead Pigment Industry
}

\author{
David Rosner and Gerald Markowitz
}

\begin{abstract}
In February 2006, in what the Rhode Island Supreme Court and others around the country called a "monumental lawsuit," a jury of six men and women held lead pigment manufacturers liable for creating what some have called the largest and longest on-going public health disaster for children in United States history. The State of Rhode Island's Attorney General's Office had initiated the suit nearly six years before charging that the historical record showed the industry had knowingly sold and profited from a product that they knew poisoned children. The attorneys representing the State argued that lead paint on the walls, woodwork, and windowsills of nearly 80 percent of the State's housing constituted a public nuisance that would lead to further cases of childhood lead poisoning in the coming years. The defense argued that the industry was not to blame. Instead, they placed responsibility for the epidemic on landlords for not maintaining their properties and on parents, most of whom were African-American and Latino, for not supervising their children more scrupulously. This article looks at the long, sad history of blaming children, parents, and even public health officials for the on-going tragedy of lead poisoning.
\end{abstract}

$I$ N February 2006, in what the Rhode Island Supreme Court and others around the country called a "monumental lawsuit" a jury of six men and women held lead pigment manufacturers liable for creating what some have called the largest and longest on-going public health disaster for children in United States history. ${ }^{1}$ The State of Rhode Island's Attorney General's Office had initiated the suit nearly six years before charging that the historical record showed the industry had knowingly sold and profited from a product that they knew poisoned children. The attorneys representing the State argued that lead paint on the walls, woodwork, and windowsills of nearly 80 percent of the State's housing constituted a public nuisance that would lead to further cases of childhood lead poisoning in the coming years. As with any public nuisance whose damage could be foreseen, the State held that action be taken to remove the lead so that children would not be in harm's way by those who had created

Dr. Rosner is Professor of History and Public Health at Columbia University in New York, NY. Dr. Markowitz is Professor of History at John Jay College and City University Graduate Center in New York, NY.

the hazard: the lead pigment manufacturers of the country. The defense argued that the industry was not to blame. Instead, they placed responsibility for the epidemic on landlords for not maintaining their properties and on parents, most of whom were African-American and Latino, for not supervising their children more scrupulously. ${ }^{2}$ Childhood lead poisoning has been identified as an environmental justice issue and this lawsuit held out the promise that future cases of lead poisoning

\footnotetext{
${ }^{1}$ The authors of this article were expert witnesses for the State of Rhode Island and testified at the trial.

${ }^{2}$ In other lead cases where individual children were suing NL Industries, manufacturers of Dutch Boy lead pigment between 1890s and the 1950s, for damages the defense has argued that the extended families of the lead poisoned were to blame because "the problems found in the children are genetic and not due to exposure to lead-based paint." [See: "Mississippi Residents Allege Lead Poisoning from Apartments," < http://injury.findlaw.com/lead/lead-news.html> (accessed: September 11, 2008)]. In a case in Milwaukee against the lead pigment manufacturers a similar "defense" was used in which defense attorneys placed responsibility for the child's neurological deficits on socialbiological history of the children and the family.
} 
could finally be prevented in Rhode Island and potentially in other states as well.

The first trial had resulted in a hung jury and in December 2005, a second trial began. The new trial lasted four months and after hundreds of hours of deposition, scores of witnesses, numerous motions to dismiss, and intense national attention, the jury decided in favor of the State and ordered that the lead industry provide funds for the abatement of the lead paint hazard by replacing lead painted windows and doorframes and the removal of lead from the walls of about 80 percent of the State's private housing stock, at a cost of anywhere from $\$ 1.2$ to $\$ 4$ billion. ${ }^{1,2}$

The decision brought into high relief the environmental damage and physical harm lead paint has caused thousands of Rhode Island children, particularly AfricanAmerican and Latino children who lived in the oldest and most poorly maintained houses in Providence and other urban communities around the state. In Rhode Island and across the country the Centers for Disease Control has documented that African American and Latino children are disproportionately affected by lead poisoning and have suffered neurological, behavioral, and physiological damage as a resulted of elevated blood-lead levels. The jury's decision, after the longest civil trial in Rhode Island history, was considered a landmark decision that could influence attorneys general around the country to bring similar lawsuits and to begin a process that would finally end the environmental scourge of lead poisoning that has affected millions of American children over the course of the past century. ${ }^{3}$

Despite the fact that the case had been nearly a decade in the making, had entailed thousands of hours of legal preparation, scores of depositions, weeks of testimony, and hundreds of thousands of documents, on July 1, 2008 the Rhode Island Supreme Court reversed the jury's decision, stating that the case was brought to court under the "wrong law" and that the suit should never have been allowed to proceed. The court ruled that "in reaching this conclusion, we do not mean to minimize the severity of the harm that thousands of children in Rhode Island have suffered as a result of lead poisoning. Our hearts go out to those children whose lives forever have been changed by the poisonous presence of lead. But, however grave the problem of lead poisoning is in Rhode Island, public nuisance law simply does not provide a remedy for this harm." 4

The Supreme Court was obviously aware of the historical significance of this case and of the enormous damage to thousands upon thousands of past victims of leaded paint. ${ }^{5}$ It was also aware that by allowing the jury decision to stand it would spur other suits by other states throughout the country, possibly resulting in the bankruptcy of major American corporations. But, we should ask other questions about the Supreme Court decision. Specifically, it is difficult not to wonder whether the decision on the narrow grounds of "wrong law" would not have been different if the children affected and the communities impacted were white and middle class. After all, if an epidemic that caused possible brain injury of another sort-say, meningitis-affected one tenth of the number of American children as did this human-made condition, we might expect that a popular uproar over the dangers to the children would lead to a massive effort to resolve the problem. But here, we are left to wonder whether the race of the children, the power of the industry, and the unwillingness of the courts to confront the historical nature of this decision to hold industry accountable led to a reversal that will condemn yet another generation of children to lowered IQs, behavioral disorders, school failure, and lives doomed before they even started. To begin to answer this question we need to understand the social history of childhood lead poisoning and the ways that the historical framing of the child-victims of lead poisoning has allowed this tragedy to continue for over a century.

\section{A BRIEF REVIEW OF THE HISTORICAL BACKGROUND}

The use of lead carbonate as a pigment for house paint led to an enormous environmental disaster as lead paint was used to cover the walls, woodwork, windowsills, ceilings, toys, and floors in homes. As we have detailed elsewhere, as early as 1900 lead pigment was identified as a "slow, cumulative poison" that affected working men and women in a variety of industries. By 1904, childhood lead poisoning was identified as a serious problem in Australia for children who crawled on lead-painted floors, who chewed on lead-painted toys, cribs, and windowsills, and who sucked on fingers covered with the fine lead dust that came off of walls and all the other objects around the house. In 1914, Henry Thomas and Kenneth Blackfan reported on cases of childhood lead poisoning in the United States in Baltimore, Maryland. ${ }^{6}$ In 1917, Blackfan published an article that reviewed the extensive English-language literature on lead poisoning in children. In his case histories he noted that children were poisoned by gnawing on lead and concluded his review with the recommendation that children should be prevented from eating or mouthing painted articles. He described children who first became "fretful, peevish and often very restless at night." Their appetite was poor and their gums began to bleed, and soon pain shot up and down their legs. Their stomachs began to ache and they became constipated. Their muscles became "so painful as not to permit the weight of the bed-clothing." They developed a waddling gait, only walking on the "outside of the feet." They dragged their toes and their legs swung out sideways as they walked. Soon, seizures occurred and some died. ${ }^{7}$

In the 1920s, clinicians produced a drumbeat of articles that linked lead-based paint to lead poisoning among children. ${ }^{8}$ These early casualties were signs of a much deeper problem that was not being addressed. Isaac Abt argued in his standard text on pediatrics that childhood lead poisoning was "more common in children than generally supposed," 9 a point that was echoed over and over in the coming years. In 1924 the Journal of the American Medical Association published an article by John Ruddock that showed that the true extent of lead poisoning in children was understated because there were "many mild cases ... 
manifested by spasms or colic, the true nature of which are never suspected." ${ }^{10}$ In 1926, Charles F. McKhann, a Harvard physician, detailed seventeen case studies, concluding that lead poisoning was "of relatively frequent occurrence in children" and was usually associated with the ingestion of lead paint. ${ }^{11,12}$

From almost the first articles published, the issue of the social class of children affected by lead poisoning marked the problem. In part this resulted from the fact that the demographic composition of urban America had begun a dramatic change during the late nineteenth and early twentieth centuries as the cities along the East coast and Midwest expanded rapidly and as immigrants and working class peoples migrated to the jobs located in the bustling ports and growing industrial towns. As the populations of cities like Baltimore, New York, Boston, and Chicago expanded so too did paints-both leaded and non-leaded-become a cheaper alternative to the wallpapers and wood finishes that were often popular among the middle class and wealthy in the mid to late nineteenth centuries. $^{13}$

The expanding market for paint produced a vibrant and aggressive competition among the scores of local manufacturers. Some companies produced paint using non-lead pigments such as lithopone, zinc and, in the 1920s, titanium-based pigments. But a few companies emerged as the producers of lead pigment, marketed as the "purest," "whitest" pigment available. As the housing stock of working-class and middle class houses expanded, so too did the spreading of lead over virtually every surface young children would come in contact with.

The competitive market for paint led to intense attention to children as a tool in attracting parents to lead products. In Figure 1 the basic approach is simply laid out: the National Lead Company, producers of the famous Dutch Boy lead paint line, implored distributors to give paint books to children who accompanied their parents into the store. The ad told of the value that the promotion had in reaching parents who "appreciate little concerns" shown to the children and to children themselves. Imbedded in some of the early ads were appeals to middle class homeowners whose own sense of place and stability had been threatened by a number of demographic forces altering the landscape of northern communities. In Figure 1, National Lead marketed its product by showing the Dutch Boy, with a suburban house cradled in his left arm holding a bucket of lead paint. The house was being sheltered from the "elements:" The snow (apparently blowing from the North), the sun (apparently beating down from the West) and a storm in the form of a racist Sambo-like depiction of a storm cloud (apparently threatening from the South). Coming in the 1920s during the first AfricanAmerican migration from the south, the message was clear: use lead paint to protect yourselves from the threats to your middle class home.

The paint books this ad was promoting were designed to entice children to believe that lead based paints protected them and their toys from the various dangerous forces, generally wind, rain, snow that threatened them. Also, they aimed at convincing children that the quality

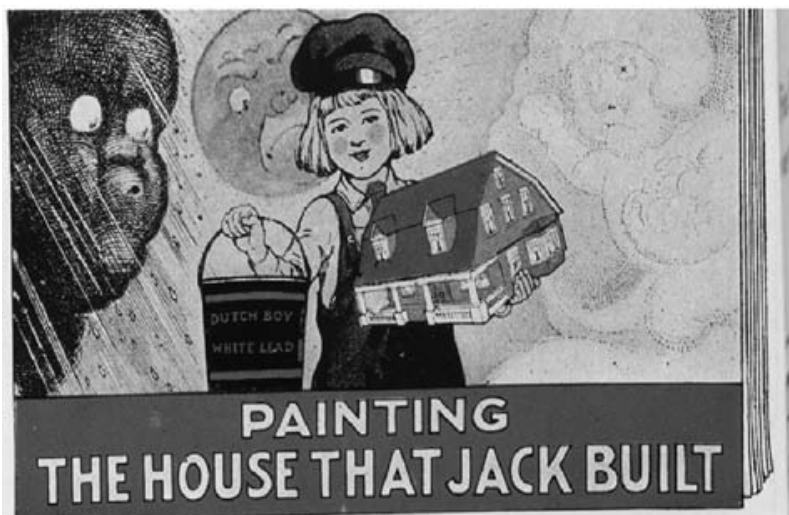

Do Not Forget the ChildrenSome Day They May Be Customers

We are not even overlooking the children in our campaign for a record paint business this fall. The children's paint book, which is reproduced in only two colors above, carries a paint message to the grown-ups, while its jingles and "pictures" amuse the little ones. Moreover, in the back of the book there is a special paint message to the parents.

By all means do not hand out these children's paint books at random. One way is to hand a copy to each youngster who comes into your store with a parent. Parents appreciate little attentions of this sort paid their children. They like to trade at stores where the youngster is not overlooked. Another effective method is to mail the paint books to the children of prospective customers. Accompany the book with a pleasant little personal letter, working in subtly a few references to your store and the "Save the Surface" idea. There are other ways to distribute these clever little books, which you no doubt will work out to your advantage. Order a supply of these children's paint books today.

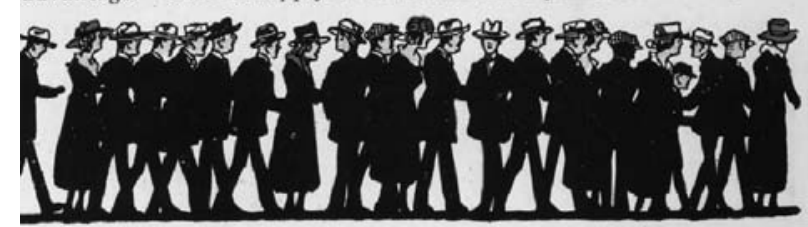

FIG. 1. Advertisement, "Do Not Forget the Children" National Lead Company, 1920.

of their lives would be enhanced by the addition of bright colors to their surroundings, including their toys and furniture (See Figure 2).

As late as 1949 National Lead remained particularly proud of their marketing campaign to children. "Thousands of homes and offices still have souvenir figures [of the Dutch Boy Painter] in the form of paper weights, statuettes, etc. The appeal was particularly strong to children and the company has never overlooked the opportunity to plant the trademark image in young and receptive minds. One of the most successful promotions for many years was a child's paint book containing paper chips of paint from which the pictures (including, of course, several Dutch Boys) could be colored .... The company still will loan a Dutch Boy costume-cap, wig, shirt, overalls and wooden shoes - to any person who writes in and asks for it for any reasonable purpose, and the little painter has graced thousands of parades and masquerades." This marketing of the Dutch Boy image was seen as an essential element of National Lead Company's profitability and the rise of its sales "from $\$ 80,000,000$ in 1939 to more than 


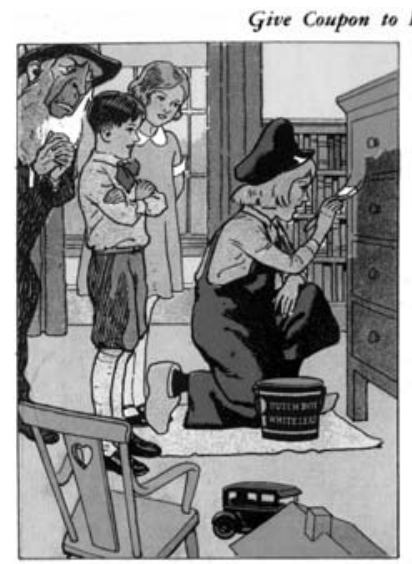

And as the work went on and on The old and shabby room was gon And sunny colors, soft and gay. Made it a lovely place to play.

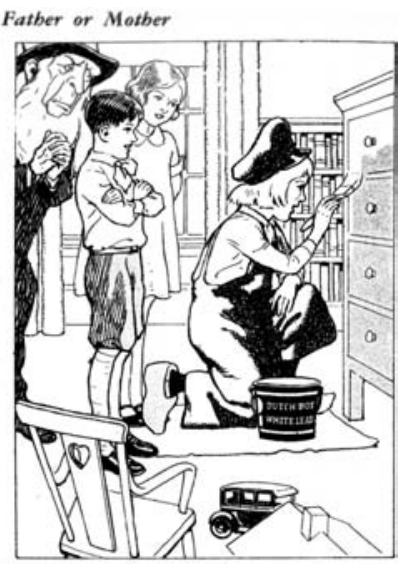

Then Old Man Gloom cried: "It's a fact That $I$ will have to change my act. "By Dutch Boy art and Dutch Boy Lead!" My work is all undone!" he said,

FIG. 2. "The Dutch Boy Conquers Old Man Gloom, National Lead Paint Book for Boys and Girls, 1929.

$\$ 320,000,000$ in 1948."14 The continuing use of the "Dutch Boy" image was understood by the broader marketing industry as a clever method for improving the image of National Lead. In 1949, one marketing journal noted that "putting the boy, with his wooden keg and brush, in the attitude of a house painter, gave animation to the subject, tied him up with the product and suggested that the quality of the paint was so good that even a child could use it." $^{\prime 15}$

\section{EARLY VICTIM BLAMING}

At the time (and even in some cases to the present), the lead industry and its defenders argued that the real "culprit" where lead poisoning was concerned was the child. ${ }^{16}$ They were able to do so because in the 1920s many viewed a child's lead poisoning as the result of pathological behavior on the part of the child. Some of the physicians reporting cases of lead poisoning in children described the poisoning as a consequence of another condition, pica, often considered an abnormal craving for non-edible substances; to make such a diagnosis put the child's own behavior in question, for pica was often associated with mental retardation. Others argued, however, that the problem was not the child's behavior but the fact that there were too many opportunities for children to put lead in their mouths. For these physicians, pica, if the term was used, was a normal habit, not a pathology. This distinction had enormous social and political implications for the lead industry: if the ingestion of lead was defined as due to the pathology of a small number of individual children, then the lead industry could justify the continued use of lead. But, if this gnawing and mouthing were a habit normal in children, then the number of potential victims of poisoning would be increased astronomically, and the industry's responsibility less easily skirted.
Today, defenders of the lead industry argue that the medical literature was long dominated by the view that only certain children engaged in the "perverse" behavior of sucking on objects and were thus at risk. However, even a cursory survey of the articles that reported on childhood lead poisoning reveals no such clear-cut understanding of the term "pica." In a survey of sixty-two such articles published between 1840 and 1939 twenty used the term "pica" or "perverted appetite," and only six of the sixty-two defined pica as a "pathological condition." In most cases it was described as part of children's normal behavior or a mild habit. Holt's Diseases of Childhood, a standard pediatrics text published in 1934, noted that pica was a habit that was not confined to mentally deficient children; the 1940 edition noted that "Most of the children who acquire [lead poisoning] do so during the first two years of life when it is natural for them to put things in the mouth. The abnormal persistence of this trait, pica, in older children may be followed by lead poisoning." 17

Others echoed the view of pica as a habit, rather than a pathological condition. Charles McKhann and Edward Vogt, in a 1933 article in the Journal of the American Medical Association argued that there were different forms of pica and that "in the majority of cases of lead poisoning due to ingestion of paint, the pica has apparently been merely a pernicious habit, unrelated to any underlying abnormal condition." ${ }^{18}$ McKhann and Vogt note that "the incidence of lead poisoning is highest in infants and small children in whom teeth are erupting and in whom there is a great tendency to put things into the mouth."19

For the most part, sucking on fingers covered with lead dust, placing toys and other objects in one's mouth, biting nails and chewing cool, sweet objects like painted windowsills or lead soldiers were understood as normal behavior for young children. In the evolving field of psychology, developmental theorists and psychoanalysts identified a variety of stages of child development; the early years were viewed as a stage when children tended to put any object they could grasp into their mouths. For Freudians, this was deemed the "oral" stage. Many who observed children simply noted that, in the normal act of teething, children would chew and gnaw on objects.

Childhood lead poisoning was a condition arising both from a set of behaviors typical of young children and the opportunity to ingest a poison. From the very beginning of the literature on lead poisoning, it was clear that this was an unusual condition, one that could not simply be attributed to abnormal behavior, but an environmental disease in that it was related to the widespread availability of the poison itself. Unlike arsenic or other toxic substances, which had only limited availability and were distributed with warning labels or skull-and-crossbones to let people know their danger, lead was everywhere and there was no warning as to its hazards. As John Ruddock put it, "a child lives in a lead world."20

\section{BLAMING THE PARENTS}

From early on parents were identified by the industry as a major reason why children were lead poisoned. Chil- 
dren were unsupervised, it was argued, and unsupervised children suffering from pica ingested lead paint by gnawing on objects around the house. In summaries of his activities in 1952, the Director of Health and Safety of the Lead Industries Association (LIA), Manfred Bowditch, called childhood lead poisoning "a major 'headache' and a source of much adverse publicity." He counted 197 reports of lead poisoning in nine cities of which 40 were fatal, although he noted that this was a "incomplete" estimate, especially for New York City. ${ }^{21}$ In New York, 44 cases were reported of which 14 were fatal. Between 1951 and 1953, according to George M. Wheatly, of the American Pediatrics Association, as reported in the New York Times, "there were 94 deaths and 165 cases of childhood lead poisoning . . . in New York, Chicago, Cincinnati, St. Louis, and Baltimore."22

Reports from health departments, publicized in the popular press, were demonstrating the widespread nature of the lead paint hazard. In 1952 the LIA collected "nearly 500 newspaper clippings featuring lead poisoning, often in sizable headlines." 23 The LIA noted a headline from the New York Daily News, "Lead Poisoning Killed 10 Kids in Brooklyn in '55, Highest Toll in the City," that was "based largely on data from the Health Department." 24 In addition to "the common run of newspaper studies on childhood and other types of plumbism," the LIA noted two "items of adverse publicity transcending [them] in importance." In July 1956 Parade magazine, which reached over 7,000,000 readers in 50 newspapers across the country, ran an article entitled, "Don't Let YOUR Child Get Lead Poisoning," and the CBS television network also carried a broadcast on childhood lead poisoning. ${ }^{25}$

The LIA recognized as early as 1952 that to continue fighting a rear-guard action attacking the extent of the lead poisoning problem would be "prohibitively expensive and time-consuming." 26 But they continued to deflect responsibility for this tragedy away from the industry itself, placing the blame on poverty, not on the lead industry: "the major source of trouble is the flaking of lead paint in the ancient slum dwellings of our older cities, [and] the problem of lead poisoning in children will be with us for as long as there are slums." 27 Bowditch acknowledged "that the overwhelmingly major source of lead poisoning in children is from structural lead paints chewed from painted surfaces, picked up or off in the form of flakes, or adhering to bits of plaster and subsequently ingested." But who was responsible for this condition? According to Bowditch and the LIA, "Childhood lead poisoning is essentially a problem of slum dwellings and relatively ignorant parents." He maintained that lead poisoning was "almost wholly confined to the older cities of the eastern third of the country" and that "until we can find means to (a) get rid of our slums and (b) educate the relatively ineducable parent, the problem will continue to plague us." 28 At the Annual Meeting of the Lead Industries Association in 1957 Bowditch provided the public rationalization for why lead poisoning was not a respojnsibklity of the industry. "The problem of lead poisoning in children," Bowditch maintained, "will be with us for as long as there are slums." Bowditch placed the blame on families and parents. "Because of the high death rate, the frequency of permanent brain damage in the survivors, and the intelligence level of the slum parents, it seems destined to remain as important and as difficult as any with which we have to deal." ${ }^{29}$ Bowditch, in private correspondence, made clear who precisely he meant by "ineducable parents." In a letter to Felix Wormser in July 1956, Bowditch complained that lead poisoning was "a serious problem from the viewpoint of adverse publicity." He reiterated his concern that the issue was basically one of "slums," saying, "the basic solution is to get rid of our slums, but even Uncle Sam can't seem to swing that one." In light of the unwillingness of the political system to rebuild inner cities, the next possible means of addressing lead poisoning was to "educate the parents." But even this he rejected as impossible: "most of the cases are in Negro and Puerto Rican families and how," he rhetorically asked Wormser, "does one tackle that job?"30

The President of the National Paint, Varnish and Lacquer Association (NPVLA), General Joseph F. Battley, elaborated on this theme, but used contemporary psychological explanations for rationalizing away corporate responsibility for the pollution of children's environments. There may be dietary deficiencies, but even "a well-fed child," he said, "may still be emotionally hungry because he does not receive as much loving attention as he needs. Another may suffer from a sense of insecurity. To gain the comfort and reassurance they crave, they often place inedible objects [i.e., flaking paint] in their mouths." ${ }^{31}$ As late as 1959, lead poisoning was still a "headache" for the industry. ${ }^{32}$ From the industry's point of view, the pollution of the urban environment was insoluble. The consequence of that viewpoint has been the destruction generations of African American and Latino children.

\section{DENYING INFORMATION TO THE “INEDUCABLE”}

At the same time that Bowditch and the lead industry was arguing that the parents were "ineducable" [sic] the industry was actively seeking to deny the necessary education to the very people they were blaming. This was particularly apparent in the debate over "warning labels" and local regulations that would limit the use of lead paint. During 1954, a variety of city, state, professional, and industry groups addressed the issue of what type of warning New York City should require on paint sold in the city. In general, the city officials wanted warning labels on paint containing more than 1\% lead. In May 1954 the Board of Health of New York City "asked that a draft of a proposed sanitary code change be submitted to it in connection with paints and coatings containing excessive amounts of lead." It proposed the following wording: "No person shall have, keep or offer for sale in the City of New York any liquid coating material or paint which contains lead compounds of which the lead content . . . is in excess of $1 \%$." It also required a warning label: "Warning: This paint contains lead-unsafe-poisonous-and should not be used to paint children's toys or furniture, 
or interior surfaces in dwelling units which might be chewed by children." 33

Some of the pigment manufacturers reacted negatively to the proposed warning. Paul Whitford, a manager in the Eagle Picher Company, wrote to the NPVLA that "the proposed section of the Sanitary Code, as set forth by Jerome Trichter, . . . demands the immediate and concerted effort of our committee to prevent the enactment of this legislation. The adoption of this proposal by the Board of Health by the city of New York, places an unprecedented stigma upon the Paint Industry by demanding the labeling of innumerable shelf goods and specialty products as unsuitable for use." ${ }^{34}$ (By 1958, when New York City was considering banning the use of lead paint on the interiors of buildings and apartments, Eagle Picher's Paul Whitford claimed that such restrictions are "certainly in order and if properly enforced should remove much of the stigma and unfavorable publicity arising from the nutritional deficiencies of children."35) The NPVLA pushed for a very different warning that emphasized paints' flammability as well as its dangers from ingestion. While explicitly saying, "Do not apply on toys, furniture or interior surfaces that might be chewed by children," it did not have the word "poisonous" in its proposal. ${ }^{36}$ The American Medical Association suggested in September of that year that the following warning be put on all paint: "WARNING: this paint contains an amount of lead which may be POISONOUS and should not be used to paint children's toys or furniture or interior surfaces in dwelling units which might be chewed by children." 37

The New York City Board of Health, at its October 29, 1954 meeting, adopted a warning label similar to the ones above but without the word poison or poisonous. The NPVLA noted that although "originally the word 'poison' was proposed for the label of paints containing lead," it had been removed and the final wording was the "result of cooperation between the New York City Health Department officials and representatives of the new York and National Paint, Varnish, and Lacquer Association."38 The LIA also claimed some credit: "The initial proposal of the New York City Health Department to require a poison label on all paints containing any lead whatsoever was ultimately modified through the establishment, at our instance, of a committee of the American Standards Association which evolved a standard permitting up to one per cent lead in paints used on surfaces which 'might be chewed by children,' thus allowing the inclusion of lead dryers in such paints. The 'poison' wording was also modified." 39 They were particularly proud that "modification of the New York City lead paint labeling regulation was secured by means of American Standard Z66.1, prepared by a committee of the American Standards Association, sponsored by the Lead Industries Association." They noted that "the futility of the labeling approach has been brought to the attention of health officials in other large municipalities and appears to have caused them to reconsider any such plans." 40 The LIA saw warning labels as a less serious threat than governmental regulation. "Every effort is being made to confine the regulatory mea- sures ... to the field of warning labels, which, as applied to paints, are obviously less detrimental to our interests than would be any legislation of a prohibitory nature."41 But even here the LIA did not concede any action it did not need to. Bowditch told Felix Wormser, now an Assistant Secretary in the Department of Interior in the Eisenhower Administration, that he made every effort to cultivate the "good will" of public health officials "and get them into a receptive frame of mind as to our viewpoint." Bowditch bragged that he believed that his efforts had "paid off, as, for example, in Chicago, where we have been able to stave off a paint labeling regulation like that here in New York." 42

In 1958 New York City proposed a revision of its regulation of the use of lead paint containing more than $1 \%$ lead, prohibiting its use on interior walls, ceilings, or window sills of any apartment or room, tenement, multiple dwelling, or any one or two family home. The reaction of officials in the NPVLA was predictably ambivalent. E.P. Hubschmitt, on the NPVLA's Subcommittee on Uniform Labeling continued to maintain, despite the mounds of evidence, that the ingestion of lead was not a serious hazard. In a review of the proposed code he told members that "many persons of note, . . . question the hazardous effects of lead by ingestion. I can recall that there is in fact very little evidence, indeed, in the medical reports to support incidences of death by ingestion of lead." 43 By 1960 even consultants for the NPVLA acknowledged that "the dried film of paint may present a hazard during removal by sanding or burning, if chewed by children, or if the loose paint is eaten by children." This conclusion was circulated by the NPVLA to the members of the Subcommittee on Toxicology and Labeling and has been approved by them for circulation to the Scientific Committee. This was done because it "summarize[d] the present state of knowledge as to the toxicity of our industry's products ...." 44

The LIA reported that the mid 1950s "was an active period in state legislatures" and that they "followed proposed legislation closely." In New York State, "a protest was filed with the proper legislative committee in New York State against a bill dealing with paint that would be unnecessarily harmful to both the paint and lead industries." The Association proudly informed its members that "the bill did not come out of committee." 45 Even though the proportion of lead in paint had been dramatically reduced in the early 1950s as titanium, zinc, and water based vinyl coverings took over a larger share of the market, the industry continued to be vigilant to any attempts to inform the public about the dangers of their product. When forced, on New Year's Eve 1957, to accept the reality of warning labels on paint products, the Association knew labels were better than other kinds of regulation: "Every effort is being made to confine . . . regulatory measures ... to the field of warning labels which, as applied to paint are obviously less detrimental to our interests than would be any legislation of a prohibitory nature." 46 In 1958, there was what the Association called a "veritable wave" of precautionary labeling legislation proposals and maintained that "watching for adverse leg- 
islation in our many states is an important part of our work and one in which the help of our members . . . is again and earnestly asked." 47

Even by the mid 1950s the industry continued to deny responsibility for a situation that had been developing for nearly a half century. Its long-term claim that the industry had done everything it could to be responsible seemed fatuous in view of the fact that the emergency wards and hospitals of cities and communities were filled with children poisoned by lead. Clearly, the use of a strong warning label indicated to the public that the industry fully understood that their product was dangerous. Therefore, the industry refocused attention on the parents, children, and even the landlord as the real source of the lead poisoning epidemic.

Despite the assertions of the industry that lead poisoning would vanish when "ancient slums" were replaced with newer dwellings, evidence that lead was still in new paint continued to appear. New York's Department of Health "disclosed [in1973] that ten companies are selling highly leaded paints in violation of the New York City Health Code." In a survey that tested "one hundred and thirty eight cans of interior paint from 23 companies ... for lead content, twenty-four cans from 10 companies were found to be highly leaded." 48 Even painted toys continued to have lead in significant quantities. In 1957, Robert Kehoe analyzed toys from a variety of companies, including Mattel and Marx, two of the nation's largest manufacturers, and found that the paints that one Chicago toy manufacturer used on its red trailer trucks contained over 34 per cent lead. Mattel's Jack in the Box was painted with red paint containing 10 percent lead and Marx' red fire truck had 3.75 per cent lead. ${ }^{49}$

It seems that no amount of evidence, no health statistics, no public outrage could get industry to care that their lead paint was killing and poisoning children. Industry viewed any mention of the dangers of lead as a public relations disaster. Until the end they continued to wear moral blinders and to counter bad publicity rather than address the problem. By 1959, when childhood lead poisoning had clearly entered the popular culture through articles in Parade magazine and television news programs on CBS, the LIA was still engaged in efforts to restrict public attention to the issue. When the LIA learned that the popular television show, Highway Patrol, had in one of its episodes referred to lead poisoning in a young boy, the Association's representatives convinced the producers to eliminate the offending reference. "We now have their verbal agreement to eliminate all reference to the toxicity of lead in an episode of lead of the series which reflected no credit on the metal or on the producers themselves," the LIA proudly announced in its Quarterly Report. ${ }^{50}$

The negative publicity about lead paint was of concern because it "hurts business" and had resulted in "thousands of items in unfavorable publicity every year," the industry association argued. Bad publicity "may even mean that your product won't be used at all because your potential customer doesn't want the problems that the use of lead may involve." 51 Yet the Association continued to deny culpability, claiming 1) that childhood lead poisoning was primarily a problem of the eastern slums and 2) was a result of the lack of education, racial inferiority, and inattentiveness of poor people. They continued to see the problem as a "headache," as a public relations issue, rather than as a public health disaster, and they feared onerous public regulation. "In the first place, [lead poisoning] means thousands of items of unfavorable publicity every year. This is particularly true since most cases of lead poisoning today are in children and anything sad that happens to a child is meat for newspaper editors and is gobbled up by the public. It makes no difference that it is essentially a problem of slums, of public welfare problem. Just the same the publicity hits us where it hurts." 52 Industry representatives attended meetings where childhood lead poisoning was addressed, negotiated with producers to revise scripts on television that mentioned lead poisoning, and continued sponsoring research that they believed would exonerate lead as a serious threat. As the publicity about lead poisoning expanded, smaller cities began to test their own children and, as with the lead poisoning epidemic historically, the more they looked, the more poisonings they found. The LIA acknowledged that there had been "something of a change" in their understanding of the eastern and big city nature of the epidemic as they began to find reports of childhood lead poisoning in communities in rural areas and small cities as well. Lead poisoning was no longer just a problem of "the slums of our older and larger cities," but was now appearing in "smaller centers" like Albany, New York; Springfield, Massachusetts; Covington, Kentucky; and Gastonia, North Carolina. ${ }^{53}$

The problem of childhood lead poisoning, long hidden from the public by the industry itself, finally emerged as a major public issue in the 1960s as community activists, public health officials, and a variety of journalists and environmentalists made the link between lead poisoning and urban poverty. By the late 1960s activists such as the Young Lords in New York City were even taking blood samples of children living in poorer communities, leading public health officials to acknowledge the depths of the problem. As Christian Warren argues in his book, Brush With Death, "vigorous, direct community agitation for a political or bureaucratic response [to lead poisoning] played out in many cities and towns during the late 1960s." At the time, activists pointed out the lethargic response to the hundreds of thousands of cases of lead poisoning in poor communities throughout the country when compared to the national campaign waged against another childhood threat, polio. ${ }^{54}$ By the late 1960s, even the lead industry acknowledged the dangers of their product, while never admitting culpability for its past misdeeds. ${ }^{55}$

For the past decade lawsuits by representatives of children poisoned by lead against the lead industry have highlighted the terrible impact of this history of victim blaming. In general, lawyers for these children have argued that the long history of knowledge and neglect on the part of the lead industry demands that finally the lead industry contribute to solving this problem. As John Mc- 
Connell, one of the leading attorneys in these lawsuits, put it at a recent trial, "this case is about companies that sold, marketed and promoted white lead carbonate for use in paint for decades. And during that entire time, they knew that it could poison children. Let me repeat that. These defendants, each one of them, knew when they sold white lead carbonate that it would hurt, and they sold it, and they marketed it, and they promoted it anyway. And now they'll claim no responsibility for the injuries that have been caused . . ."56 At this same trial, the position of the industry replicated the historical arguments outlined in this article: children, parents, landlords, even the government and public health departments were to blame for lead poisoning. But above all, it was the child who needed to "change his attitude" and stop looking to society or the industry for any help. For example, despite having been diagnosed with an extraordinarily high blood-lead level, ${ }^{3}$ the defense attorney for NL Industries blatantly argued in some recent cases that it was unfair to blame lead for the children's problems. In his closing statement in one of these cases he told the jury that, despite the fact that the child had very high blood-lead levels, it was probably not lead that was responsible for all his intellectual, emotional, and behavioral problems. Rather, it was the child's negative attitude that had caused him to fail at school, act out in various social situations, and get in trouble with the law. If the young man was in the courtroom, Michael Jones, the attorney for NL Industries told the jury, "I'd say to him, you can, and God dog it, you must change your attitude. Your attitude is the principal thing holding you down in life. That is what I would say to [him]." ${ }^{\prime 7}$ In another case in Mississippi the same lawyer represented NL Industries in a suit brought by African-American parents on behalf of their children by arguing that "the problems found in the children are genetic and not due to exposure to lead-based paint." 58 Victim blaming plays well with juries who are often unwilling to award an African-American child who has dropped out of school or who has had trouble with the law or who is, in general, assumed to have no future anyway, large sums of money.

For much of the century, the lead industry produced, marketed, and profited from the sale of lead paint for use in housing around the country. From the 1920s on there is strong historical evidence that they understood that lead paint was poisoning children. Yet, for much of the century the industry was able to deflect attention from its own role in perpetrating a problem by focusing the nation's attention on a host of other forces that fed the problem. Children with pica, "ignorant" parents, children who weren't supervised, and, in the 1960s, slum landlords who profited from dilapidated housing were identified as the culprits. Obviously, parents who were denied information about the dangers of lead, children who were told through advertisements and booklets that lead protected health and improved the quality of life, caretakers who were too overwhelmed to watch children's every movement, and landlords whose own profits depended on little or no maintenance can be seen as part of the larger constellation of actors who might have held differing roles in the tragedy. And certainly the children who have and will be lead poisoned because of paint that covers the nation's walls are the big losers. But only one actor in this historical drama has remained immune from the tragedy: the lead industry that knowingly sold and profited from, and which actively promoted, the use of this dangerous product. They left it there knowing the future damage it would cause-and will continue to cause because of the Rhode Island Supreme Court's decision to overturn the verdict in State v. Lead Industries Association.

\section{ENDNOTES}

1. See State v. Lead Industries Association, Inc., 898 A.2d 1234, 1235 (R.I. 2006).

2. Rhode Island Supreme Court, Opinion in State of Rhode Island v. Lead Industries Association, Inc., et al., No. 2004-63-M.P. No. 2006-158-Appeal. No. 2007-121-Appeal. (PC 99-5226): Present: Williams, C.J., Flaherty, Suttell, and Robinson, JJ.

3. The Rhode Island Supreme Court summarized the history of the case thusly: "After a four-month trial, which concluded on February 22, 2006, a jury found defendant manufacturers, NL Industries, Inc. (formerly National Lead Co.) (NL), The Sherwin-Williams Co. (SherwinWilliams), and Millennium Holdings LLC (Millennium) (collectively defendants), liable under a public nuisance theory. Both before and after the jury returned its verdict, the trial justice issued nineteen written decisions, ruling on a variety of pretrial, trial, and post-trial motions that both the state and defendants had filed." See Rhode Island Supreme Court, Opinion in State of Rhode Island v. Lead Industries Association, Inc., et al., No. 2004-63-M.P. No. 2006-158-Appeal. No. 2007-121-Appeal. (PC 99-5226): Present: Williams, C.J., Flaherty, Suttell, and Robinson, JJ.

4. Rhode Island Supreme Court, Opinion in State of Rhode Island v. Lead Industries Association, Inc., et al., No. 2004-63-M.P. No. 2006-158-Appeal. No. 2007-121-Appeal. (PC 99-5226): Present: Williams, C.J., Flaherty, Suttell, and Robinson, JJ., p.4.

5. See State of Rhode Island v. Lead Industries Association, Inc., No. PC 99-5226, 2007 R.I. Super. LEXIS 32 (Feb. 26, 2007); see also Peter B. Lord, "Jurors in lead-paint trial say they're proud of verdict," The Providence Journal, Mar. 12, 2006, at B1; Lisa A. Perillo, "Note: Scraping Beneath the Surface: Finally Holding Lead-Based Paint Manufacturers Liable by Applying Public Nuisance and Market-Share Liability Theories?" 32 Hofstra L. Rev. 1039, 1041 (2004).

6. Henry Thomas and Kenneth Blackfan, "Recurrent Meningitis, Due to Lead in a Child of Five Years," American Journal of Diseases of Children 8 (November 1, 1914), 380, 377. A. Brent, W. J. Young, "The Occurrence of Lead Poisoning Amongst North Queensland Children," $A n$ -

${ }^{3}$ The child's blood-lead level was $49 \mu \mathrm{g} / \mathrm{dL}$ (micrograms of lead per deciliter of blood, nearly five times the level the Centers for Disease Control defines as "elevated" and which has been identified as a level at which various behavioral, neurological, and intellectual deficits can occur). 
nals of Tropical Medicine and Parasitology 8 (January 1, 1914), 575-590.

7. Kenneth D. Blackfan, "Lead Poisoning in children with Especial Reference to Lead as a Cause of Convulsions," American Journal of Medicine 153 (1917), 877-887.

8. See, for example, Robert Strong, "Meningitis Caused by Lead Poisoning in a child of Nineteen Months," Archives of Pediatrics 37 (January 1, 1920); L. Emmett Holt, "General Function and Nervous Diseases," in The Diseases of Infancy and Childhood for the Case of Students and Practitioners of Medicine, Chapter 11, 8th ed., (New York: D. Appleton, 1923), pp. 645-694; L. Emmett Holt, "Lead Poisoning in Infancy," American Journal of Diseases of Children 25 (March, 1923); Councilof Queensland Branch ... . "An Historical Account of the Occurrence and Causation of Lead Poisoning Among Queensland Children," Medical Journal of Australia 1 (February 11, 1922). Stafford McLean and Ruston McIntosh, "Studies of the Cerebral Spinal fluid in Infants and Young Children," in The Human Cerebrospinal Fluid New York, 1924, pp. 299-300; Carl Vernon Weller, "Some Clinical Aspects of Lead Meningo-Encephalopathy," Annals of Clinical Medicine 3 (1925), 604-613; Joseph Aub, Lawrence Fairhall, A.S. Minot, Paul Reznikoff, and Alice Hamilton, Lead Poisoning (Baltimore: The Williams and Wilkins Company, 1926), p.70 and preface; L. Emmett Holt and John Howland, The Diseases of Infancy and Childhood (NY: D. Appleton and Co., 1926), p.542; Frederick L Hoffman, Deaths from Lead Poisoning, U.S. Department of Labor, Bureau of Labor Statistics, Bulletin No. 426, (Washington, DC: GPO, February 1927), pp. 33-34; Boston, Health Department, "Lead Poisoning in Early Childhood," Monthly Bulletin 16 (Nov. 1927), 266.

9. Issac Abt, ed. Pediatrics, vol. VII, Philadelphia, 1925, 246-7; 315.

10. John Ruddock, "Lead Poisoning in Children with Special Reference to Pica," Journal of the American Medical Association 82 (May 24, 1924) p. 1682. In 1926 another American researcher, in an article entitled, "Lead Poisoning in Children," noted that lead paint was dangerous to children and that "many cases of lead poisoning are overlooked" by physicians and parents, suggesting that the first thing to do was to make parents aware "of the hazards of painted articles to little children." See L. W. Holloway, "Lead Poisoning in Children," Journal of the Florida Medical Association 13 (1926) 94-100; Frederick Hoffman, Deaths from Lead Poisoning, U.S. Bureau of Labor Statistics, Bulletin No. 426, in which he lists eleven boys and eight girls under the age of eighteen who died from lead poisoning, a number of whom were poisoned from eating the paint from windows, walls, toys, and cribs.

11. Charles F. McKhann, "Lead Poisoning in Children," American Journal of Diseases of Children 32 (1926), 386-392.

12. This information is detailed in our book, Deceit and Denial: The Deadly Politics of Industrial Pollution (University of California Press/Milbank Fund, 2002).

13. For a more detailed history of the evolution of the lead paint hazard, see Gerald Markowitz and David Rosner, Deceit and Denial: The Deadly Politics of Industrial Pollution (University of California Press/Milbank Fund, 2002) and Christian Warren, Brush with Death: A Social History of Lead Poisoning, (Johns Hopkins University Press, 2000).

14. National Lead Company, Sales Manual, "Important," [ca. 1949] LIA papers.
15. ——, Modern Packaging, April 1949.

16. See "Affidavit of Peter C. English," City of New York et al. Against Lead Industries Association, Inc., et al. Index Number 14365/89, 1999.

17. Emmitt Holt and John Howland, "Neuroses of the Alimentary Tract," Holt's Diseases of Infancy and Childhood (New York: D. Appleton, 1934), p. 764; 1940 edition, p. 1368.

18. Charles McKhann and Edward Vogt, "Lead Poisoning in Children," JAMA 101 (1933), 1131. See also Charles F. McKhann, "Lead Poisoning in Children," The Archives of Neurology and Psychiatry 27 (February 1932), 294-295. He acknowledged that some children chewed paint because they were anemic, or had "certain intestinal parasites," or were prone to pica as a result of mental defects, but that most "do not fit into any of these groups, but appear normal children who have merely a pernicious habit."

19. Charles McKhann and Edward Vogt, "Lead Poisoning in Children," JAMA 101 (1933), 1131.

20. John Ruddock, "Lead Poisoning in Children with Special Reference to Pica," Journal of the American Medical Association 82 (May 24, 1924) p. 1682. Carl Vernon Weller, "Some Clinical Aspects of Lead Meningo-Encephalopathy," Annals of Clinical Medicine 3 (1925), 604-613; See also Stafford McLean and Rustin McIntosh, "Studies of the Cerebrospinal Fluids in Infants and Young Children," in The Human Cerebrospinal Fluid (New York: Paul Hoeber, 1924), pp. 299-300; T. Suzuki and J. Kaneko, "Serious Meningitis in Infants Caused by Lead Poisoning from White Powders," Journal of Oriental Medicine January 1, 1924.

21. Manfred Bowditch to Mr. Ziegfield, "1952 Activities," Dec. 16, 1952; LIA, Annual Meeting, April 9-10, 1953, "Lead Hygiene."

22. New York Times November 9, 1954, p. 26.

23. LIA, Annual Meeting, "Lead Hygiene," April 9-10, 1953, LIA papers.

24. LIA, "Quarterly Report of the Secretary," April 2, 1956, LIA papers.

25. LIA, Quarterly Report of the Secretary, October 1, 1956, LIA papers.

26. Bowditch to Ziegfield, December 16, 1952, courtesy of Christian Warren.

27. LIA, Report of Health and Safety Division, Manfred Bowditch, Director Annual Meeting, April 24-25, 1957, LIA papers.

28. Bowditch to Kehoe, December 26, 1957, Courtesy of Christian Warren.

29. LIA, Report of Health and Safety Division, Manfred Bowditch, Director, 29th Annual Meeting, (April 24-25, 1957), LIA Papers.

30. Bowditch to Wormser, July 11, 1956, LIA Papers.

31. National Paint, Varnish and Lacquer Association, "Watch Your Child's 'Eating Habits'!” NCA 000053.

32. LIA, Annual Report for 1959, LIA papers.

33. Jerome Trichter to C.W. Slocum, August 24, 1954, LIA Papers.

34. Paul Whitford to John C. Moore, September 2, 1954, LIA Papers.

35. Paul Whitford to Joseph F. Battley, May 27, 1958, LIA Papers.

36. "Precautionary labels Recommended by the National Paint, Varnish and LacquerAssociation . . .," in Battley, 
president, NPVLA to Members of the Executive Committee ... October 6, 1954, LIA Papers.

37. Bernard E. Conley to Jerome Trichter, September 9, 1954, LIA Papers.

38. NPVLA, Minutes, Toxic Materials Committee Meeting, October 27, 1954, "Confidential" EPI 000840; New York City Department of Health, Press Release, November 10, 1954, LIA Papers.

39. LIA, Annual Report for the Year 1955, p. 6, LIA Papers.

40. LIA, "Report of Health and Safety Division," 28th Annual Meeting, April 24-25, 1956.See also LIA, "Annual Report for the Year 1956": "Publications relative to lead hazards have been watched and, where, warranted, the attention of authors has been called to unduly adverse statements." LIA Papers.

41. LIA, Quarterly Report, April 2, 1958, p. 2, LIA Papers.

42. Bowditch to Wormser, July 11, 1956, LIA Papers.

43. E.P. Hubschmitt, "A Review of the Second Draft Copy of Title IV: Dealing with the Sanitary Code, New York City," in Hubschmitt to Members of the Subcommittee on Uniform Labeling, Subject: Ref. File Misc. \#44EUnifrom Paint Labeling Law, September 15, 1958, LIA Papers.

44. A.E. Van Wirt, "Suggestions on Toxicological Study," June 14, 1960, LIA Papers; Francis Scofield to Members of the Scientific Committee: Toxicological Study, June 14, 1960, LIA Papers.

45. LIA, "Quarterly Report of the Secretary, January 1 to March 31, 1956," April 2, 1956, LIA Papers.

46. LIA, "Quarterly Report of the Secretary, October 1 to December 31, 1957," January 10, 1958, LIA Papers.

47. LIA "Report of Health and Safety Division," 30th Annual Meeting, April 15-16, 1958, LIA Papers.

48. Vincent F. Guinee, M.D. [NYC Department of Health] to Naomi Feigelson, Jan. 5, 1973, “Subject: News ReleaseIllegal Paint," LIA Papers.

49. Folder: "Lead in Paint on Children's Toys," [1957] Kehoe Papers, Box 39.
50. LIA, "Quarterly Report of the Secretary, July 1 to September 30, 1959," October 8, 1959. LIA, Annual Report for 1959, LIA Papers.

51. LIA, Annual Report for 1959, LIA Papers.

52. LIA, Annual Report, 1959, LIA Papers.

53. LIA "Quarterly Report of the Secretary, April 1 to June 30, 1960," July 1, 1960, LIA Papers.

54. Christian Warren, Brush with Death: A Social History of Lead Poisoning, (Baltimore: Johns Hopkins University Press, 2000), 187.

55. See, for example, LIA, "Minutes, Meeting of Board of Directors," April 14, 1969, LIA Papers; "Lead Industry Response to Legislation Against Lead Paints," "Draft$8 / 5 / 69$ " in which the industry emphasizes that the problem lay with "old" paint, not with their newer products and that the answer to the problem lay primarily in education and maintenance.

56. Opening Argument for the Plaintiff, John McConnell, in Steven Thomas, Plaintiff, v. Clinton L. Mallett, et al., Defendants. Case No. 99CV006411, Jury Trial Transcript, November 1, 2007, Volume 24, p. 1097-1098.

57. Closing Argument for the Defense, Michael Jones, Steven Thomas, Plaintiff, v. Clinton L. Mallett, et al., Defendants. Case No. 99CV006411, Jury Trial Transcript, November 1, 2007, Volume 24, p. 6247-6248.

58. See "Mississippi Residents Allege Lead Poisoning from Apartments," <http://injury.findlaw.com/lead/leadnews.html $>$ (accessed September 11, 2008).

Address correspondence to:

David Rosner

Mailman School of Public Health

Columbia University

722 West 168th Street

9th Floor

New York, NY 10032

E-mail:dr289@columbia.edu 